Article

\title{
Nutrient Storage and Stoichiometry of the Forest Floor Organic Matter in Japanese Forests
}

\author{
Masamichi Takahashi ${ }^{1,2}$ (D) \\ 1 Japan International Forestry Promotion and Cooperation Center, Rinyu Building, 1-7-12 Kouraku, Bunkyo-ku, \\ Tokyo 112-0004, Japan; masamichi@jifpro.or.jp \\ 2 Forestry and Forest Products Research Institute, 1 Matsunosato, Tsukuba 305-8687, Japan
}

Citation: Takahashi, M. Nutrient Storage and Stoichiometry of the Forest Floor Organic Matter in Japanese Forests. Soil Syst. 2021, 5, 51 https://doi.org/10.3390/

soilsystems 5030051

Academic Editor: Klaus von Wilpert

Received: 14 July 2021

Accepted: 24 August 2021

Published: 29 August 2021

Publisher's Note: MDPI stays neutral with regard to jurisdictional claims in published maps and institutional affiliations.

Copyright: (C) 2021 by the author. Licensee MDPI, Basel, Switzerland. This article is an open access article distributed under the terms and conditions of the Creative Commons Attribution (CC BY) license (https:// creativecommons.org/licenses/by/ $4.0 /)$.

\begin{abstract}
Nutrient storage in the forest floor is regulated through litter decomposition and nutrient cycling. Stoichiometry of nutrients can provide characterization of the forest floor. To quantify nutrient storage in the forest floor and to determine stoichiometry among different forest types, available data on nutrients were meta-analyzed. The data on nutrients-nitrogen, phosphorus, potassium, calcium, and magnesium - were collected from published reports and original data on Japanese forests. The relationship between nutrient storage and forest floor mass was also examined. Japanese cypress and cedar plantations had small $\mathrm{N}$ and $\mathrm{P}$ storage in the forest floor with high $\mathrm{C}: \mathrm{N}$ and C:P ratios, whereas subalpine conifers had large $\mathrm{N}$ and $\mathrm{P}$ storage in the forest floor with low C:N and C:P ratios; cedar plantations showed large Ca-specific storage in the forest floor. The stoichiometry of the forest floor varied between different forest types, namely $\mathrm{C}: \mathrm{N}: \mathrm{P}$ ratios were 942:19:1 for cedar and cypress plantations, 625:19:1 for broad-leaved forests, and 412:13:1 for subalpine conifers and fir plantations. N storage was closely correlated; however, P and other mineral storages were weakly correlated with the forest floor mass. Nutrient storage and stoichiometry can provide a better perspective for the management of forest ecosystem.
\end{abstract}

Keywords: C:N:P ratio; dead organic matter; forest ecosystem; forest soil; humus layer; nutrient cycling; nutrient reservoir; organic layer

\section{Introduction}

The forest floor developed over mineral soils includes organic residues-such as leaves, branches, bark, and stems - in various stages of decomposition. Forest floor organic matter forms an important carbon pool within the forest ecosystem since it makes up the organic humus layers, such as the L (Oi), F (Oe), and $\mathrm{H}(\mathrm{Oa})$ layers, and fine woody debris. The Inter-Governmental Panel on Climate Change defined this carbon pool as a "litter", separating it from soil and deadwood in the generalized category for dead organic matter [1]. Since then, there has been a large amount of data summarized on "litter" carbon stock in the recent decades [2-4]. Apart from providing this vital carbon pool for forest ecosystems, the forest floor serves as critical habitats and food sources for soil fauna and microbes, which play vital roles in litter decomposition [5]. The thickness and density of the forest floor affect the abundance and diversity of soil fauna [6,7]. Conversely, the forest floor quality, i.e., its nutrient contents and energy sources, further affects the activities of decomposers [8]. For nutrient cycling in forest ecosystems, the forest floor functions as a nutrient reservoir and chemical buffering layer against acid deposition [9-11]. Although it plays such a pivotal role in ecosystem functioning, nutrient storage within the forest floor is given much less attention in research than that of litter decomposition.

Numerous studies have been conducted on litter decomposition processes that have revealed changes in litter decomposition rate following nutrient release and/or nutrient immobilization [12-15]. The litter bag method is widely used to track the time course of nutrient dynamics within litter during the early stages of decomposition. However, the 
method has limitations in the later decomposition stages [16,17], meaning that the litter bag study does not provide accurate and suitable information on the storage of nutrients in the forest floor. Because the forest floor comprises a mixture of organic materials going through both early and late decomposition, the stratification of organic layers can enable the accurate estimation of nutrient storage in thick humus forms-moder and mor humus [18,19]; however, the subdivision is not applicable for the mull humus form. Root development in the $\mathrm{F}$ and $\mathrm{H}$ layers also affect nutrient dynamics in the forest floor [20]. Although nutrient storage in the forest floor may provide a snapshot of nutrient cycling in the ecosystem, this labile nutrient pool is important for soil fertility and soil food web. Thus, compiling data on nutrient storage in the overall forest floor of different forest types in Japan could enable further research for evaluating the importance of the forest floor as a nutrient reservoir and its chemical buffering capacity for the ecosystem.

The stoichiometry of the forest floor is a good indicator of the conditions of decomposing organic materials. Fresh fallen litter shows a large variation in nutrient contents and carbon-to-nutrient ratios among tree species gradually converge at a particular range by progressing decomposition and humification $[2,21,22]$. Since a large divergence in stoichiometry exists between fresh litter and soil [23], the stoichiometry of the forest floor, which serves as an intermediary body between them, may assist in understanding the decomposition processes and element dynamics at the soil surface boundary. In Canada, long-term litterbag experiments using 10 tree species were conducted over a six-year period [24]. The results showed a convergence in litter stoichiometry of the carbon-to-nitrogen $(\mathrm{C}: \mathrm{N})$, carbon-to-phosphorus (C:P), and nitrogen-to-phosphorus (N:P) ratios to 30,450 , and 16 , respectively, which is equivalent to a $\mathrm{C}: \mathrm{N}: \mathrm{P}$ ratio of $450: 16: 1$, based on $\mathrm{P}$ content. Ma et al. [25] studied the C:P:N ratio variations in decomposed forest floor litter at different successional stages in eastern China and found that C:N:P varied with successional vegetation stages, ranging from 377:26.5:1 to 782:57:1. Tree species and climate conditions were noted to affect the stoichiometry of the forest floor. Because Japan has a wide variety of forest types and climate conditions even in small archipelagic nations [26,27], evaluating the range of forest floor stoichiometry will be valuable to understand litter quality in various forest conditions.

The amount of nutrient storage that the forest floor can provide is greatly affected by its mass. The accumulation of this forest floor mass varies depending on site condition factors, such as soil, topography, and forest management; this is even so in a monoculture plantation [28-30]. Using the variation of the forest floor mass, carbon concentration and storage in the forest floor have been determined by the regression with dry weight of the forest floor mass adjusted by the ash content [31]. Similarly, it may be possible to develop regression equations to estimate the nutrient storage within the forest floor. Because nutrient concentrations in fresh litter varies with tree species [32], correlations may differ based on predominant tree species in a particular forest.

The aims of this study were to: (1) summarize dry weight mass and nutrient storage in the forest floor of different forest types in Japan, (2) analyze stoichiometry of organic materials in the forest floor to evaluate their quality, and (3) examine regression equations between forest floor mass and nutrient storage in the forest floor. To achieve the study aims, a meta-analysis was performed using existing data collected from scientific papers and project reports, as well as data based on the author's original research conducted in Japan.

\section{Materials and Methods}

Data on dry weight, as well as carbon and nutrient storage of the forest floor organic layer, were obtained from the existing research articles and project reports. This literature review included both English and Japanese manuscripts, and the data from the literature was combined with original data of the author to undertake the meta-analysis. Some of the data were used for compiling forest soil carbon stock in varying forests in Japan [33]. Nutrient mass within the forest floor was calculated by using the forest floor dry weight multiplied by the total concentration of nutrients: nitrogen $(\mathrm{N})$, phosphorus $(\mathrm{P})$, potassium 
$(\mathrm{K})$, calcium $(\mathrm{Ca})$, and magnesium $(\mathrm{Mg})$. Analytical methods and equipment varied between the different researchers and their respective studies. When the studied report did not provide the amount of carbon storage of the forest floor, a conversion equation was used in its place [31]. Data for all nutrients was not available for every study; therefore, the sample size for each nutrient varied among forest types.

Data were grouped based on predominant forest types, plantation, or natural and semi natural forests. The predominant forests are shown in Table 1. Plantation forestry mainly consists of Japanese cedar (Cryptomeria japonica, $44 \%$ of the total plantation area) and Japanese cypress (Chamaecyparis obtusa, 25\%). Well-drained and productive moist hills and mountain slopes in Japanese forests are largely occupied by these two species [34]. Japanese red pine (Pinus densiflora) is a representative planted and naturally established species on xeric ridges. Japanese black pine (Pinus thunbergia) is often seen planted on coastal sandy soils [35,36]. Subalpine coniferous forests are often develop on podzolic soil with thick organic layers [37,38]. Japanese larch (Larix kaempferi) and Todo fir (Abies sachalinensis) plantations are mostly distributed in cool northern prefectures $[39,40]$. Subalpine coniferous forests include cypress and fir old-growth natural forests. For broad-leaved deciduous forests, Japanese beech (Fagus crenata) covers cool temperate areas, whereas oak (Quercus spp.) widely occurs in cool and warm temperate forests [27]. Castanopsis spp. are evergreen broad-leaved species found in warm southern parts of Japan [41]. Because of the limited number of available nutrient data on broad-leaved forests, the broad-leaved species were grouped into deciduous and evergreen forests. The groups based on forest types included those with more than 10 stands and those older than 20 years. Distribution maps of sample size in a prefecture are shown in Figure 1 and Table S1. The data on Todo fir were collected only from the Hokkaido prefecture, North Island.

Table 1. Forest types and their predominant tree species in Japan.

\begin{tabular}{cl}
\hline Forest Type & \multicolumn{1}{c}{ Scientific Names of Predominant Species } \\
\hline Cedar & Cryptomeria japonica \\
Cypress & Chamaecyparis obtusa \\
Larch & Larix kaempferi \\
Pine & Pinus densiflora, P. thunbergii \\
Todo fir & Abies sachalinensis \\
Subalpine coniferous & Abies veitchii, A. mariesii, A. sachalinensis, Picea jezoensis \\
& var. hondoensis, P. jezoensis, P. glehnii, Tsuga diversifolia \\
& Fagus spp., Quercus spp., Betula spp., Acer spp., Alnus \\
Deciduous broad-leaved & spp., Carpinus spp., Pterocarya rhoifolia, Aesculus turbinata, \\
& Fraxinus spp. \\
& Castanopsis spp., Lithocarpus spp., Quercus acuta, Machilus \\
& thunbergii, Cinnamomum camphora, Camellia spp. \\
\hline
\end{tabular}

Most of the group data on nutrient storage were not normally distributed and had positive skewness. Hence, the medians and quartiles were used for the representative values. The nonparametric Steel-Dwass test was performed for multiple comparisons of all pairs of the forest types. For comparing nutrient concentrations among forest types, TurkeyKramer test was used because of normal distributions of the data. The linear regression between the dry weight of forest floor mass and the nutrient storage was conducted by using logarithm transformation. Statistical analysis was conducted using JMP software (SAS Institute Inc., Cary, NC, USA). 

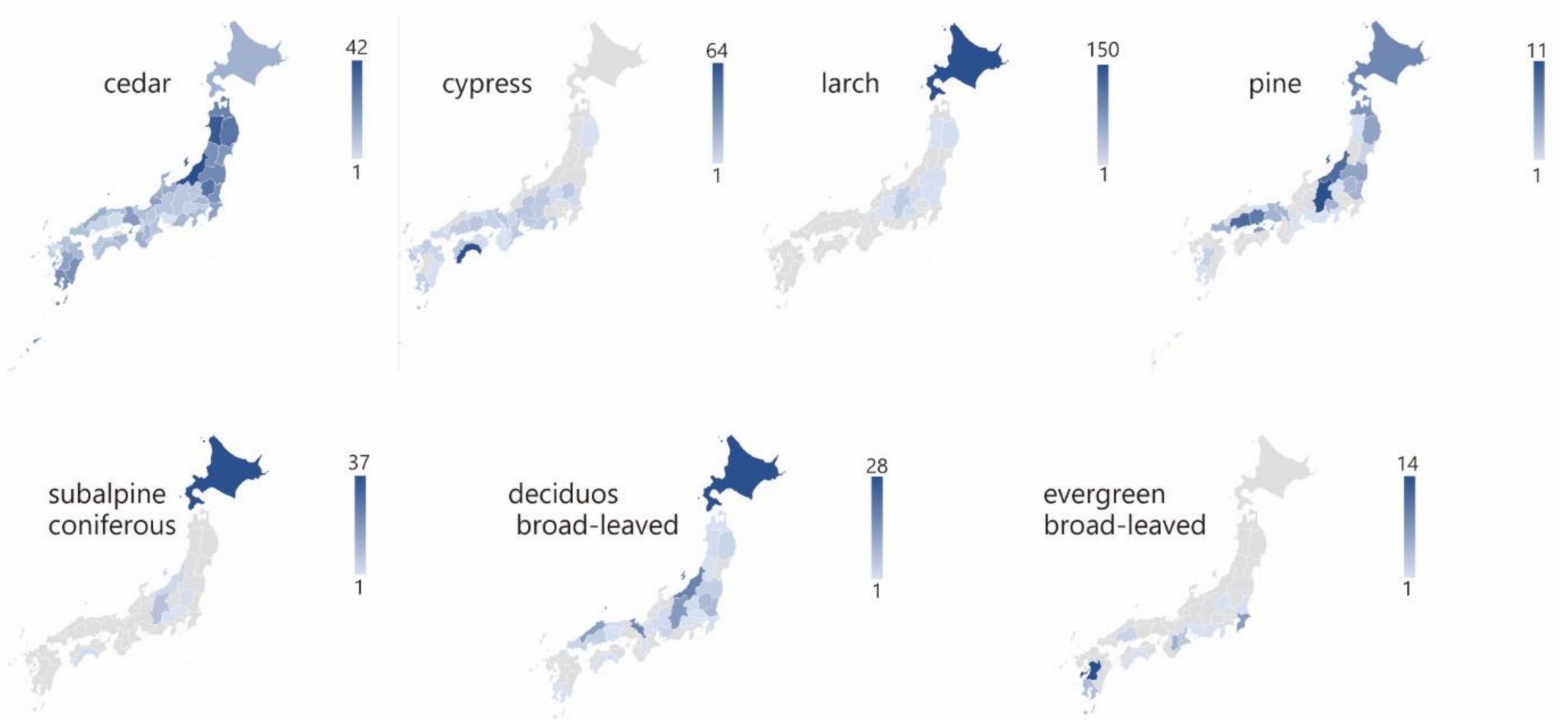

Figure 1. Distribution of the sample size of forest floor mass data in the prefecture level in Japan. Nutrient storage data are shown in Table S1.

\section{Results}

\subsection{Dry Mass and Nutrient Storage in Predominant Forest Type}

Among coniferous forest types, minimum accumulation of forest floor mass occurred in cypress plantations $\left(6.6 \mathrm{Mg} \mathrm{ha}^{-1}\right)$, followed by cedar plantations $\left(9.3 \mathrm{Mg} \mathrm{ha}^{-1}\right.$; Figure 2A, Table S2). Cypress and cedar were significantly different from the other forest types, except evergreen broad-leaved forests. The largest mass was represented by subalpine coniferous forests $\left(37.0 \mathrm{Mg} \mathrm{ha}^{-1}\right)$, and fir natural forests $\left(32.5 \mathrm{Mg} \mathrm{ha}^{-1}\right)$ next. Other coniferous forests ranged from 12.1 to $14.5 \mathrm{Mg} \mathrm{ha}^{-1}$ were mostly no significant difference. As for broadleaved forests, deciduous forests $\left(12.2 \mathrm{Mg} \mathrm{ha}^{-1}\right)$ had relatively larger forest floor mass than evergreen forests $\left(9.2 \mathrm{Mg} \mathrm{ha}^{-1}\right)$, despite of insignificance.
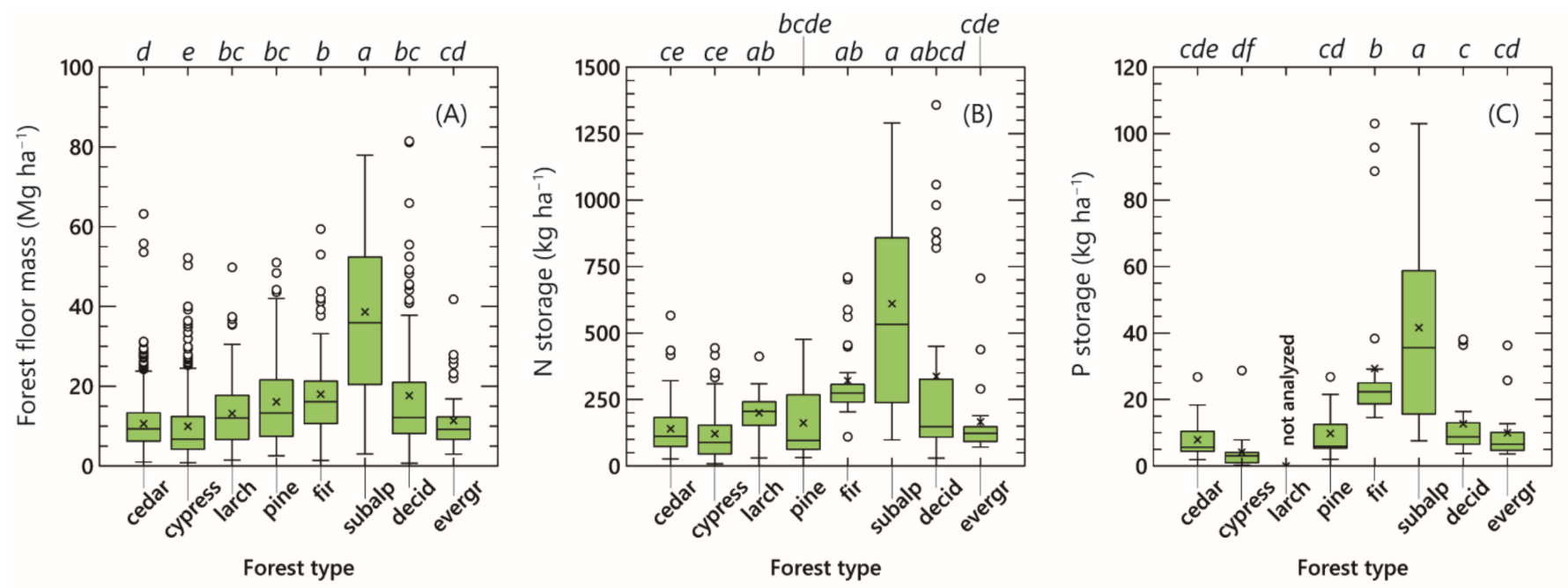

Figure 2. Box and whisker plots of forest floor mass (A), nitrogen (B), and phosphorus (C) storage in the forest floor among Japanese forest types. Subalpine coniferous forests, deciduous broad-leaved forests, and evergreen broad-leaved forests are represented by "subalp", "decid", and "evergr" respectively. The box covers the 75th and 25th percentiles. The horizontal line within the box marks the median, and the cross indicates the mean. The length of the whisker is 1.5 times the interquartile range. Outliers are indicated by open circles. Different lowercase letters on the figure denote significant differences between forest types at $p<0.05$ based on the Steel-Dwass test. 
Nitrogen storage in the forest floor showed significant variation among forest types (Figure 2B, Table S3). Among coniferous forests, subalpine coniferous forests and fir plantations had significantly larger $\mathrm{N}$ storage, at 533 and $261 \mathrm{~kg} \mathrm{ha}^{-1}$, respectively. Cedar and cypress plantations and evergreen broad-leaved forest showed significantly lower $\mathrm{N}$ storage, ranging from 89 to $123 \mathrm{~kg} \mathrm{ha}^{-1}$. Phosphorus storages were significantly small in cypress $\left(3.10 \mathrm{~kg} \mathrm{ha}^{-1}\right)$ and cedar $\left(5.66 \mathrm{~kg} \mathrm{ha}^{-1}\right)$ plantations and large in subalpine coniferous forests ( $35.6 \mathrm{~kg} \mathrm{ha}^{-1}$ ) (Figure 2C, Table S4). Evergreen and deciduous broadleaved forests also had small P storages ( $6.55 \mathrm{~kg} \mathrm{ha}^{-1}$ and $8.75 \mathrm{~kg} \mathrm{ha}^{-1}$, respectively).

Regarding mineral stocks, $\mathrm{K}$ storage was the lowest $\left(10.9 \mathrm{~kg} \mathrm{ha}^{-1}\right)$ in cypress and deciduous broad-leaved forests (Figure 3A, Table S5). Cedar plantations also showed small $\mathrm{K}$ storage in the forest floor. Compared to cedar, cypress, and deciduous broadleaved forests, significantly higher K storages occurred in subalpine coniferous forests $\left(51.6 \mathrm{~kg} \mathrm{ha}^{-1}\right)$ and fir plantations $\left(35.7 \mathrm{~kg} \mathrm{ha}^{-1}\right)$. Calcium storage was significantly higher $\left(147 \mathrm{~kg} \mathrm{ha}^{-1}\right)$ in cedar than in cypress plantations $\left(57.3 \mathrm{~kg} \mathrm{ha}^{-1}\right)$ (Figure 3B, Table S6). The highest occurred in the subalpine coniferous forest $\left(233 \mathrm{~kg} \mathrm{ha}^{-1}\right)$. Evergreen broad-leaved forests had significantly higher Ca storage than deciduous broad-leaved forests. The range of $\mathrm{Mg}$ storage in the forest floor was narrow and no significant differences were found among the forest types (Figure 3C, Table S7).
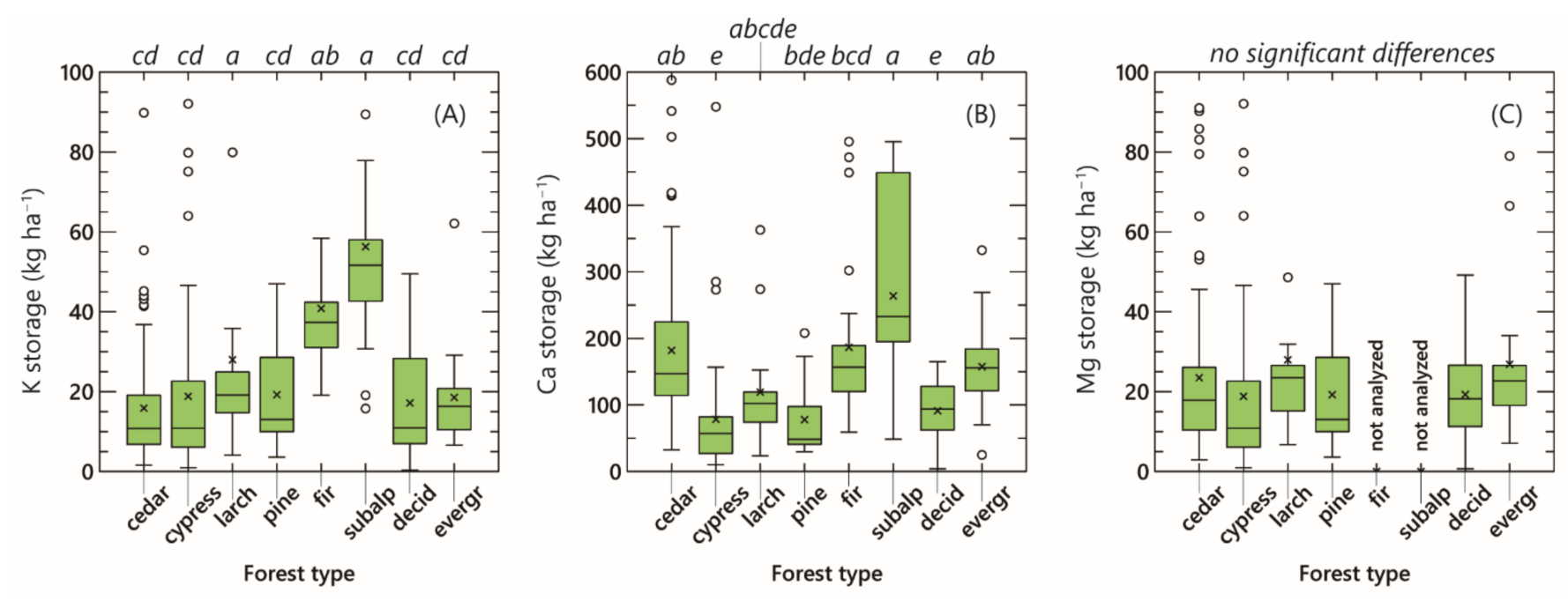

Figure 3. Box and whisker plots of potassium (A), calcium (B), and magnesium (C) storage in the forest floor among Japanese forest types. The definitions of box and whisker are the same as those used in Figure 2. Different lowercase letters on the figure denote significant differences between forest types at $p<0.05$ based on the Steel-Dwass test.

\subsection{Total Nutrient Concentrations in the Forest Floor}

Table 2 shows the nutrient concentrations of each forest type. The $\mathrm{N}$ concentration in the forest floor of broad-leaved forests was significantly higher than that of coniferous forests. The range of $P$ concentration was large; the low values (about $0.55 \mathrm{~g} \mathrm{~kg}^{-1}$ ) occurred in cedar and cypress plantations, while high values (about $1.1 \mathrm{~g} \mathrm{~kg}^{-1}$ ) were observed in fir plantations and subalpine coniferous forests. Broad-leaved forests showed intermediate $P$ concentrations. Ca concentrations in cedar plantations and evergreen broad-leaved forests were almost twice as high as the other forest types. No significant differences were detected in $\mathrm{K}$ and $\mathrm{Mg}$ concentrations of the forest floor among forest types. 
Table 2. Mean and standard deviation (s.d.) of total nutrient concentrations $\left(\mathrm{g} \mathrm{kg}^{-1}\right)$ in the forest floor of predominant forest types.

\begin{tabular}{|c|c|c|c|c|c|c|c|c|c|c|}
\hline \multirow{2}{*}{$\begin{array}{c}\text { Nutrient } \\
\text { Forest Type }\end{array}$} & \multicolumn{2}{|c|}{$\mathbf{N}$} & \multicolumn{2}{|c|}{$\mathbf{P}$} & \multicolumn{2}{|c|}{$\mathbf{K}$} & \multicolumn{2}{|c|}{$\mathrm{Ca}$} & \multicolumn{2}{|c|}{ Mg } \\
\hline & Mean ${ }^{(2)}$ & s.d. & Mean (2) & s.d. & Mean & s.d. & Mean ${ }^{(2)}$ & s.d. & Mean & s.d. \\
\hline \multicolumn{11}{|l|}{ Coniferous } \\
\hline Cedar & $10.0 \mathrm{~d}$ & 2.86 & $0.542 \mathrm{~d}$ & 0.265 & 1.24 & 0.870 & $13.9 \mathrm{a}$ & 4.27 & 1.65 & 1.05 \\
\hline Cypress & $10.0 \mathrm{~d}$ & 3.03 & $0.552 \mathrm{~cd}$ & 0.270 & 1.70 & 1.46 & $7.11 \mathrm{~b}$ & 3.72 & 1.37 & 1.11 \\
\hline Larch & $12.5 \mathrm{bcd}$ & 2.55 & n.a ${ }^{(1)}$ & n.a & 1.55 & 0.815 & $7.37 \mathrm{~b}$ & 3.34 & 1.64 & 0.64 \\
\hline Pine & $11.1 \mathrm{~cd}$ & 2.67 & $\begin{array}{c}0.770 \\
\text { bcd }\end{array}$ & 0.195 & 1.51 & 0.597 & $6.42 \mathrm{~b}$ & 2.53 & 1.84 & 1.58 \\
\hline Todo fir & $13.4 \mathrm{bc}$ & 1.90 & $1.19 \mathrm{ab}$ & 0.446 & 1.73 & 0.360 & $7.96 \mathrm{~b}$ & 3.20 & n.a. & n.a. \\
\hline Subalpine coniferous & $14.0 \mathrm{ab}$ & 3.46 & $1.09 \mathrm{a}$ & 0.624 & 1.48 & 0.574 & $7.47 \mathrm{~b}$ & 4.27 & n.a. & n.a. \\
\hline \multicolumn{11}{|l|}{ Broad-leaved } \\
\hline Deciduous & $15.5 \mathrm{a}$ & 4.83 & $0.813 \mathrm{bc}$ & 0.340 & 1.13 & 0.870 & $7.85 \mathrm{~b}$ & 6.53 & 1.33 & 0.888 \\
\hline Evergreen & $13.5 \mathrm{abc}$ & 4.48 & $0.633 \mathrm{~cd}$ & 0.270 & 1.37 & 0.647 & $13.7 \mathrm{a}$ & 10.9 & 2.16 & 1.58 \\
\hline
\end{tabular}

(1) n.a.: not analyzed due to small sample size. ${ }^{(2)}$ Values with different letters indicate significant differences between forest types at $p<0.05$ based on the Turkey-Kramer test.

\subsection{Stoichiometry of Carbon and Nutrients in the Forest Floor}

C:N ratios were significantly high in the cedar and cypress plantations-49.8 and 47.2, respectively (Figure 4A, Table S8). The C:N ratio of other coniferous forests ranged from 32.4 to 40.7. The lowest C:N ratio occurred in the deciduous broad-leaved forests (28.2). For C:P ratio, cedar and cypress plantations again showed significantly high values-957 and 914, respectively (Figure 4B, Table S9). The lowest C:P ratio occurred in the fir plantations (394). The N:P ratios of cedar and cypress plantation and broad-leaved forests were significantly higher than that of fir plantations (Figure 4C, Table S10). Fir plantations, pine forests, and subalpine coniferous forests had low N:P ratios with no significant differences. Based on $\mathrm{P}$ concentration, C:N:P ratios were 943:19.5:1 for cedar and cypress plantations, 625:19.3:1 for broad-leaved forests (deciduous and evergreen), and 412:13.0:1 for subalpine coniferous forests and fir plantations, on average.
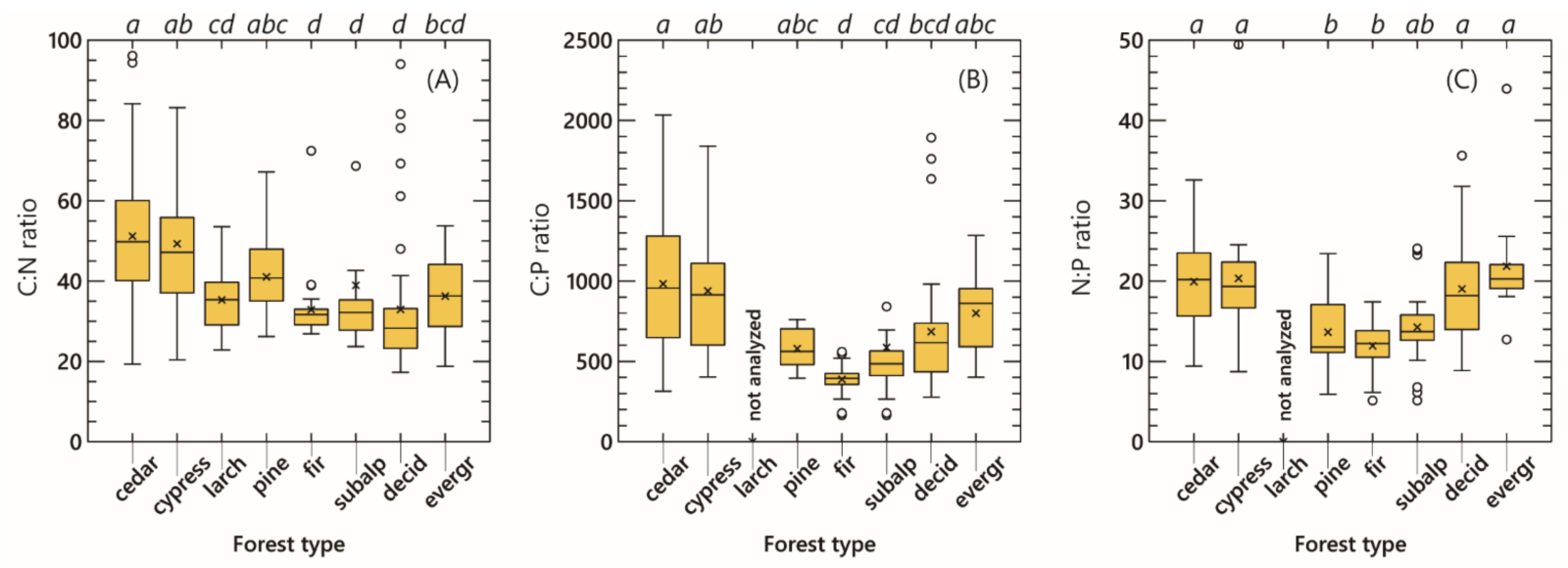

Figure 4. Box and whisker plots of stoichiometry (C:N (A), C:P (B), and N:P (C) ratios) of the forest floor among Japanese forest types. The definitions of box and whisker are the same as those used in Figure 2. Different lowercase letters on the figure denote significant differences between forest types at $p<0.05$ by the Steel-Dwass test.

Having the lowest C:Ca (34.8) was considered a special characteristic of cedar plantations. This was significant when compared with the C:Ca ratio of other forest types, which ranged from 59.9 to 72.6 (Table S11). No significant difference among forest types was found for C:Mg ratios, that is, from 267 to 444 (Table S12). Carbon-to-potassium (C:K) 
ratios were significantly lower in fir plantations (233) than in the cedar plantations (510) (Table S13).

\subsection{Relationship between the Dry Weight of the Forest Floor and Nutrient Storage}

Nutrient storage in the forest floor was significantly correlated with its dry weight for all elements $(p<0.001)$. However, the coefficient of determination $\left(\mathrm{R}^{2}\right)$ varied with the different elements and forest types (Table A1). The relationships in cedar plantations and those in deciduous broad-leaved forests are shown in Figures 5 and 6, respectively, as examples. The storage of $\mathrm{N}$ was most closely correlated with the dry weight of the forest floor mass in most forest types: the $\mathrm{R}^{2}$ of $\mathrm{N}$ ranged from 0.697 (evergreen broadleaved forests) to 0.924 (pine forests). However, except for $\mathrm{N}$, nutrient storage was weakly correlated with forest floor mass in most of elements. Particularly, the variation of the $\mathrm{R}^{2}$ was large in $\mathrm{P}$, ranging from 0.443 (cedar) to 0.903 (pine). In coniferous plantations and forests, the storages of mineral elements had moderate correlations with their forest floor mass, approximately $0.6-0.7$ in the $\mathrm{R}^{2}$, irrespective of elements and forest types. Low $\mathrm{R}^{2}$ occurred in broad-leaved forests particularly for $\mathrm{Ca}$ and $\mathrm{Mg}$, which ranged from 0.102 to 0.381 .
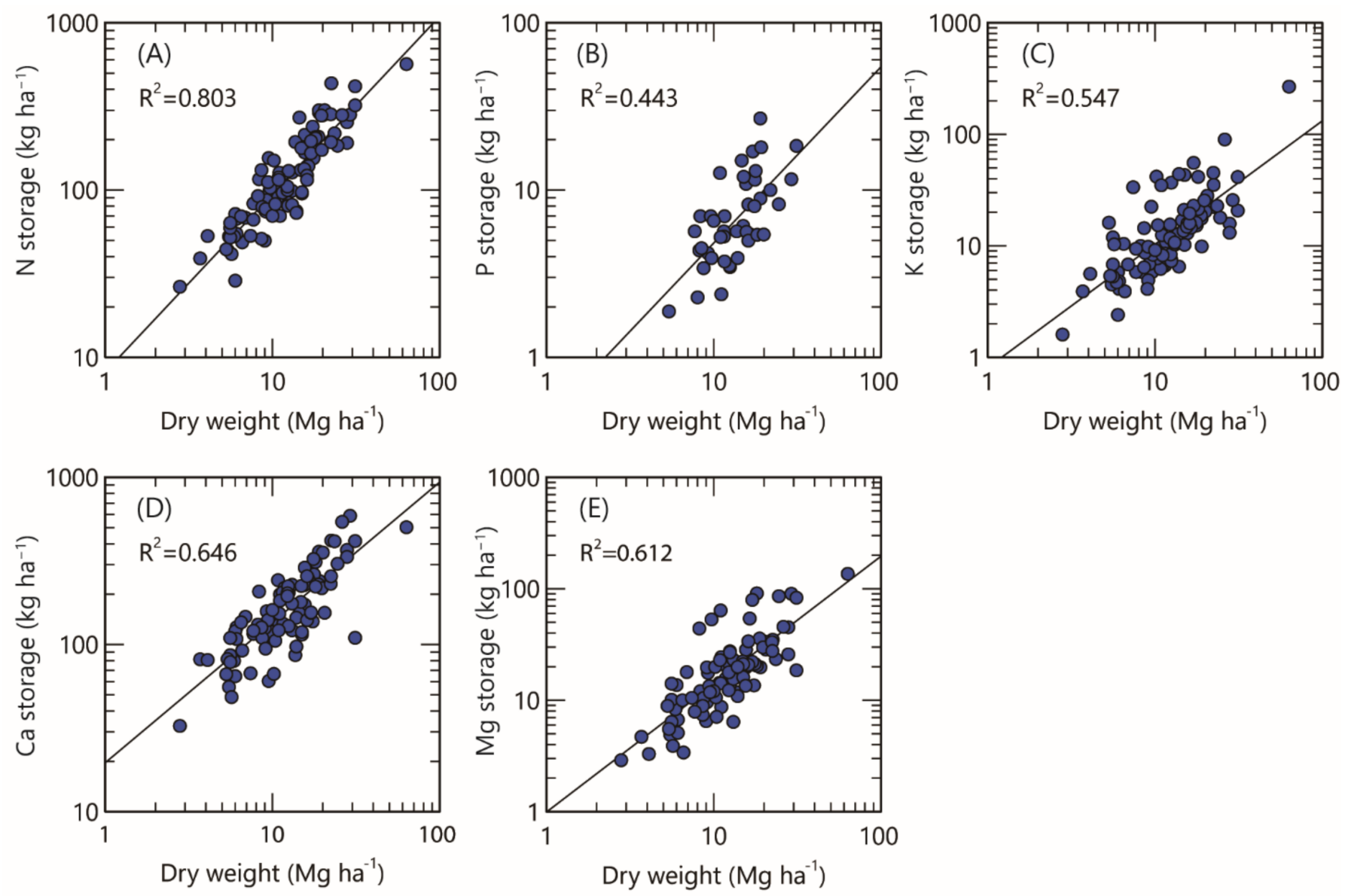

Figure 5. Relationship between nutrient storage (nitrogen (A), phosphorus (B), potassium (C), calcium (D), and magnesium (E)) and dry weight of the forest floor in Japanese cedar plantations. Regression equations are shown in Table A1. 

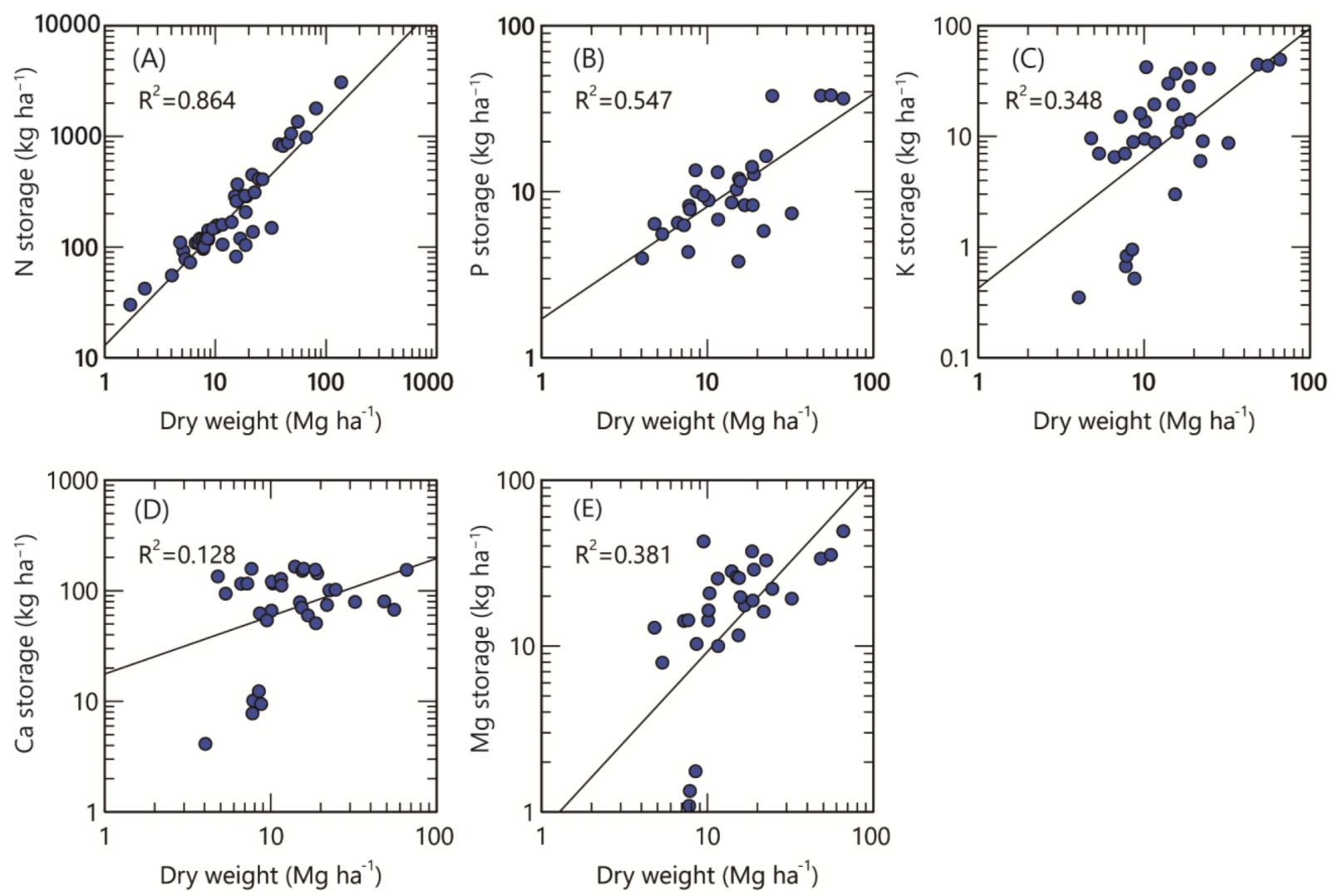

Figure 6. Relationship between nutrient storage (nitrogen (A), phosphorus (B), potassium (C), calcium (D), and magnesium (E)) and dry weight of the forest floor in deciduous broad-leaved forests in Japan. Regression equations are shown in Table A1.

\section{Discussion}

\subsection{Forest Floor Mass}

Nutrient storage is calculated by multiplying the forest floor nutrient concentration by its dry weight. Factors that play a role in developing forest floor mass should be discussed, especially for cedar and cypress plantations. According to the well-applied litter bag method, the decomposition rate of cedar and cypress leaf litter is not high when compared with other representative tree species in Japan $[13,16]$. In cypress plantations, it has often been suggested that the rapid physical fragmentation of cypress leaf litter progresses in the earliest stage of decomposition. Fresh fallen cypress leaves were fragmented quicklywithin half a year from the litter fall season-into small leaflets, which are more susceptible to erosion or migration into mineral soil [42-44]. Hence, twigs and small branches most commonly remained on the forest floor. It has been emphasized that the forest floor is generally sparsely distributed in cypress plantations with a partly uncovered surface soil [42,45-47], which might explain the small mass of its forest floor.

In cedar plantations, soil macro fauna, such as earthworms and soil crustaceans, are abundant $[48,49]$. A higher population of soil fauna is reported in cedar plantations compared to cypress plantations $[16,48,50]$. These faunal activities seem to be responsible for the rapid decomposition of cedar litter. Mesofauna was also likely to contribute to cedar litter decomposition. Kaneko et al. [16] found that oribatid mites invade the inside of the cedar needle litter to ingest it, creating a hollow within leaves that could be detached from rachis in early decomposition stages. Consequently, rachis, petioles, twigs, and cones most commonly remained on the forest floor, likewise cypress plantations. Fallen branches were also scattered as bundles of foliage in cedar plantations [16]. Although the forest floor consisted of a mixture of organic materials going through both early and late decomposition stages, in cedar and cypress plantations, easily decomposable litter parts 
disappeared quickly, with recalcitrant woody organic materials dominating the forest floor, which is consistent with our findings that cedar and cypress forest floors had high C:N and $\mathrm{C}: \mathrm{P}$ ratios.

The forest floor of old-growth natural cypress forests developed a thick mass at $44.8 \mathrm{Mg} \mathrm{ha}^{-1}$ (Table S2), which was different from their plantations. The large forest floor mass was supposed to resulted from specific site conditions, such as dense understory dwarf bamboo and slow litter decomposition in cool climate regions [51,52]. Besides cool climate conditions, such large amounts of the forest floor in old-growth forests may be responsible for a long steady-state period for accumulating organic matter in forest floor without disturbances and harvesting. Similarly, the forest floor mass in natural fir forests $\left(32.5 \mathrm{Mg} \mathrm{ha}^{-1}\right)$ is larger than those in fir plantations $\left(14.5 \mathrm{Mg} \mathrm{ha}^{-1}\right)$ in Hokkaido prefecture.

\subsection{Nutrient Storage of Nitrogen and Phosphorus}

The lowest and second-lowest $\mathrm{N}$ storage occurred in cypress and cedar plantations at 89 and $111 \mathrm{~kg} \mathrm{ha}^{-1}$, respectively. Phosphorus storage was also low in these forest floors, at $3.10 \mathrm{~kg} \mathrm{ha}^{-1}$ for cypress and $5.66 \mathrm{~kg} \mathrm{ha}^{-1}$ for cedar plantations. Furthermore, high C:N and C:P ratios within these forest floors suggest that net $\mathrm{N}$ and $\mathrm{P}$ mineralization does not progress during organic matter decomposition. These findings suggest that the forest floor, in situ, rarely functions as an available nutrient reservoir in the ecosystem. In addition, it is known that cedar litter has high N-fixing activity levels during decomposition [53] but that the high C:N ratio and low $\mathrm{N}$ storage suggest that $\mathrm{N}$ fixation contributes little toward $\mathrm{N}$ storage. Fragmented litter that physically migrated to the A horizon, as discussed above, may then serve as available $\mathrm{N}$ and $\mathrm{P}$ to vegetations.

On the contrary, in subalpine and cool temperate plantations of larch and fir, large amounts of $\mathrm{N}$ and $\mathrm{P}$ were stored in the forest floor, which was probably due to the slow litter decomposition taking place in the cool climate. Among broad-leaved forests, beech forests distributed in cool regions also stored large $\mathrm{N}$ amounts $\left(450 \mathrm{~kg} \mathrm{ha}^{-1}\right)$ in the forest floor (Table S3). Moreover, C:N and C:P ratios were low in these forest floor. Thus, the forest floor could function as an actual nutrient pool for these ecosystems, despite slow decomposition of litter. The observation that fine roots systems were developed in the $\mathrm{F}$ and $\mathrm{H}$ layers $[18,19]$ indicates the tight relationships between tree growth and forest floor nutrient in the ecosystems. These findings inspire fragile ecosystem of subalpine forests, such that if the site conditions were changed-through climate change and forest disturbances like harvesting and typhoon damage-the nutrient pool will be directly disturbed and would then release large amounts of $\mathrm{N}$ and $\mathrm{P}$ from the forest floor. Recovery from the disturbances may then require time to again form the necessary thick forest floor.

\subsection{Mineral Storage in the Forest Floor}

It is a special characteristic of cedar plantations that a considerably high amount of $\mathrm{Ca}$ can be stored even within the thin forest floor. The total Ca concentration was significantly higher in the forest floor of cedar plantations. Several studies reported that exchangeable $\mathrm{Ca}$ in the A horizon was higher in cedar plantations than in other forest types $[49,54-56]$. The abundance of faunal decomposers, such as soil crustaceans and earthworms, seemed to be related to Ca richness in the forest floor $[48,49]$. The Ca concentrations in the fresh fallen cedar leaves were relatively higher among the tree species in Japan, averaging at $17.9 \mathrm{mg} \mathrm{g}^{-1}$ [32]. Harada et al. [57] reported that the Ca concentration of the bark of Japanese cedar was considerably higher at $9.5-23.1 \mathrm{mg} \mathrm{g}^{-1}$, when compared to its other parts. Considering the high C:N ratio in the forest floor, the high Ca storage in the forest floor may partly be responsible for the recalcitrant bark of cedar trees.

High Ca storage of the forest floor is likely to play a large buffering capacity for acid deposition. Baba et al. [55] observed that a large amount of exchangeable Ca was leaching from the cedar forest floor, which alleviated the Ca loss by proton load. Takahashi [58] demonstrated that the Ca present in needle litters became water soluble when the decomposing needles became black, suggesting that an increase in the water solubility contributes 
to Ca mobility from the litter to A horizon. However, such Ca behavior does not contribute $\mathrm{Ca}$ accumulation in the forest floors. Further studies are still needed to understand how high Ca concentration and storage develop in the forest floor of cedar plantations.

Significantly high $\mathrm{K}$ and $\mathrm{P}$ storage were found in subalpine and cool temperate coniferous forests. It was reviewed that the strong correlation between $\mathrm{P}$ and $\mathrm{K}$ concentrations observed in the fungal component of symbiotic ectomycorrhizal and arbuscular mycorrhizal fungi suggests that $\mathrm{P}$ transport to plants was accompanied by $\mathrm{K}$ ion [59]. K is a typical ion that is quickly released from fresh litter in initial decomposition stages [60]. However, it might be caught by fungal hyphae developed in the F layers of forest floors [19,61], resulting in large $\mathrm{K}$ storage in the forest floor of cool ecosystems. Additionally, some mushrooms are known to act as a $\mathrm{K}$ accumulator in forest floors [62-64]. Both $\mathrm{K}$ and $\mathrm{P}$ storage may be partly controlled by fungal activity in thick forest floors. Mg storage in the forest floors did not clearly show any special tendency among the forest types despite the small numbers of samples. On the basis of this, $\mathrm{Mg}$ may have little biological interaction with decomposers in the forest floor.

\subsection{Stoichiometry}

The interquartile ranges (IQRs) of C:N, C:P, and N:P ratios among the forest types were narrow when compared with those of nutrient storage elements themselves (Tables S8-S10). Although data were collected from varying prefectures with varying site conditions, the stoichiometry of the forest floor ranged within narrow ratios depending on the specific forest type. Cedar and cypress plantations showed high $C: N, C: P$, and N:P ratios, with broad-leaved forest types showing low $C: N$ and $C: P$ ratios and a high $\mathrm{N}: \mathrm{P}$ ratio. The forest floor in subalpine and fir plantations had low $C: N, C: P$, and N:P ratios.

The ratios of $C: N, C: P$, and N:P of fresh fallen litter are generally in the range of 100 and more, 1000 and more, and between 30 and 50, respectively. They are decreasing gradually by mineralizing $C$ sources [23]. The high C:N and C:P ratios of the forest floor under cedar and cypress plantations suggests that the forest floor consists of relatively young organic materials, i.e., only passing through a short time after senescence. For estimating the decomposition rate of the forest floor organic matter, the residence time of the forest floor can be calculated using annual litterfall data [9,20]. According to a review by Saito [65], total litterfall including branches averaged $5.15 \mathrm{Mg} \mathrm{ha}^{-1}$ in cedar plantations and $4.41 \mathrm{Mg} \mathrm{ha}^{-1}$ in cypress plantations. Therefore, the mean residence time of the forest floor (forest floor mass/litterfall) of cedar plantations, and cypress plantations are 1.81 and 1.52 years, respectively. When compared with subalpine coniferous forests-having $4.28 \mathrm{Mg} \mathrm{ha}^{-1}$ of annual litterfall [65] - the residence time at the forest floor is much longer (8.72 years) than that of cedar, cypress, and broad-leaved forests. The residence time indicates nutrient availability as well. Lang [66] reported that the mean residence time of the forest floor can be used as a P recycling indicator, with turnover rates of the forest floor increasing with accompanying increasing total P stocks in the soil systems of European beech forests. Long residence times in subalpine coniferous forests suggest that the forest floor provides available $\mathrm{P}$ and probably $\mathrm{N}$ with slow rates.

As for the N:P ratio, fungal biomass and physiology may regulate $\mathrm{N}$ and $\mathrm{P}$ dynamics, which are both affected by temperature regime. Reich and Oleksyn [67] found that leaf $N$ and $\mathrm{P}$ concentrations and $\mathrm{N}: \mathrm{P}$ ratios decreased with decreasing mean annual temperature. Li et al. [68] also showed that soil microbial $\mathrm{N}$ and $\mathrm{P}$ concentrations increased, while microbial N:P ratios decreased with decreasing temperature regime. Such effects of temperature on fungal activities would be obvious in moder and mull humus forms in subalpine and cool temperate forests due to high fungal biomass in the F layer $[19,61]$.

Because the land in Japan is widely influenced by volcanic materials, the andic properties of soil often have high $\mathrm{P}$ adsorption capacities that act as inhibitors of $\mathrm{P}$ availability $[69,70]$. Higher N:P ratios in the forest floor of cedar and cypress plantations might be affected by the interaction of mineral soils with andic properties because of soil contamination in the thin forest floor. 


\subsection{Correlation between Dry Weight of the Forest Floor and Nutrient Storage}

It was expected that positive correlations between dry weight and nutrient storage in the forest floors existed because the nutrient storage was calculated using the parameter of dry weight. However, the correlations were usually weak for most of the elements, except for N (Table A1). Furthermore, the correlations between dry weight and nutrient concentration in the forest floors were weak (data are not shown; $R^{2}$ are 0.000 to 0.268 ). $\mathrm{N}$ dynamics in the forest floor would be closely reflected by $\mathrm{C}$ mineralization processes by decomposers, but the nutrient concentration in the forest floor seems to be affected by factors other than forest type and leaf litter decomposition. Geochemical factors, such as mineral associations of $\mathrm{P}$ as is discussed above, might influence the $\mathrm{P}$ concentration in the forest floors [71,72]. Vogt et al. [20] reported that input of organic matter from fine-roots developed in the forest floor is a crucial factor, decreasing the mean residence time and nutrient turnover rate of forest floor in fir forests of USA. Such mechanisms may occur in our dataset; the subalpine coniferous forests showed relatively weak correlation with low $\mathrm{R}^{2}$ for all elements. Since deciduous and evergreen broad-leaved forest groups are composed of various tree species, lower $R^{2}$ values are unavoidable. Organic acid production in the thick organic layer and nitrate formation through nitrification may militate decrease in cations in the forest floor $[73,74]$. Other factors were also pointed out for forest floor nutrient conditions: soil fertility [75], forest age [76], and understory vegetation [77]. Furthermore, external environmental factors affect nutrient condition of the forest floor. Acid deposition accelerated the leaching of exchangeable cations [10,78,79]. Thus, accurate estimation of nutrient storage in the forest floor from the dry weight of forest floor mass is not recommended except for $\mathrm{N}$, due to the effects of variation of nutrient concentration by various reasons.

\section{Conclusions}

A meta-analysis was applied to data for obtaining information on nutrient storage and stoichiometric ratios of the forest floors of predominant forest types in Japan. In cedar and cypress plantations established in fertile sites, the forest floor stored low $\mathrm{N}$ and $\mathrm{P}$ with high $\mathrm{C}: \mathrm{N}$ and C:P ratios, suggesting that the forest floor plays only a minor role as a nutrient reservoir. Subalpine coniferous forests and fir plantations in cool climates had large $\mathrm{N}$ and $\mathrm{P}$ storage with low C:N and C:P ratios in the forest floor, which indicates that nutrient resource and availability are largely dependent on the forest floor despite of slow organic matter decomposition. Japanese cedar plantations are characterized by having large $\mathrm{Ca}$ storage in a relatively thin forest floor layer, suggesting a high chemical buffering capacity for acid depositions. Stoichiometry is a useful tool for estimating the quality of the forest floor. The difference in the stoichiometry seems to be reflected by the processes of litter decomposition and the composition of decomposing organic materials in the forest floor. Nitrogen storage was closely related to the dry weight of the forest floor, but $\mathrm{P}$ and mineral element storage were not. Because the forest floor is a labile pool of nutrients against forest management and climate conditions, the knowledge of the storage size and stoichiometry of nutrients in the forest floor can provide a better perspective for tree species selection in plantation forestry, ecosystem management, and climate change impact. Lastly, the statistical values in this study may be biased due to the maldistribution of sample positions and imbalances in sample size. Systematic sampling can improve the grasp of the whole aspect of forest floor quality and quantity of Japan.

Supplementary Materials: The following are available online at https: / www.mdpi.com/article/ 10.3390 / soilsystems5030051/s1. Table S1. Sample size of forest floor mass and nutrients in the prefecture of Japan; Table S2. Statistics of dry weight $\left(\mathrm{Mg} \mathrm{ha}^{-1}\right)$ of forest floor of different forest types; Table S3. Statistics of nitrogen storage $\left(\mathrm{kg} \mathrm{ha}^{-1}\right)$ in the forest floor of different forest types; Table S4. Statistics of phosphorus storage $\left(\mathrm{kg} \mathrm{ha}^{-1}\right)$ in the forest floor of different forest types; Table S5. Statistics of potassium storage $\left(\mathrm{kg} \mathrm{ha}^{-1}\right)$ in the forest floor of different forest types; Table S6. Statistics of calcium storage $\left(\mathrm{kg} \mathrm{ha}^{-1}\right)$ in the forest floor of different forest types; Table S7. Statistics of magnesium storage $\left(\mathrm{kg} \mathrm{ha}^{-1}\right)$ in the forest floor of different forest types; Table S8. Statistics of 
C:N ratio in the forest floor of different forest types; Table S9. Statistics of C:P ratio in the forest floor of different forest types; Table S10. Statistics of N:P ratio in the forest floor of different forest types; Table S11. Statistics of C:Ca ratio in the forest floor of different forest types; Table S12. Statistics of $\mathrm{C}: \mathrm{Mg}$ ratio in the forest floor of different forest types; Table S13. Statistics of C:K ratio in the forest floor of different forest types.

Funding: This research received no external funding.

Acknowledgments: I thank K. Ishizuka, S. Ohta, and M. Kato for establishing the monitoring protocols for measuring forest floor mass in a project funded by the Forestry Agency of Japan which triggered this study. I also thank two anonymous reviewers and the academic editor for their valuable comments on the manuscript.

Conflicts of Interest: The author declares no conflict of interest.

\section{Appendix A}

Table A1. Parameters and the coefficient of determination $\left(R^{2}\right)$ for regression lines between elements/nutrients within and dry weight of the forest floor (FF) using the following equation: $\log _{10}\left(\right.$ element, $\left.\mathrm{kg} \mathrm{ha}^{-1}\right)=\mathrm{a}+\mathrm{b} \log _{10}\left(\mathrm{FF}, \mathrm{Mg} \mathrm{ha}^{-1}\right)$.

\begin{tabular}{|c|c|c|c|c|c|}
\hline Element & Forest Type & $\mathbf{a}$ & $\mathbf{b}$ & $\mathbf{R}^{2}$ & $\mathbf{n}$ \\
\hline \multirow[t]{8}{*}{ Nitrogen } & Cedar & 0.916 & 1.063 & 0.803 & 98 \\
\hline & Cypress & 0.899 & 1.083 & 0.871 & 52 \\
\hline & Larch & 1.053 & 1.031 & 0.893 & 16 \\
\hline & Pine & 0.941 & 1.089 & 0.924 & 21 \\
\hline & Todo fir & 1.038 & 1.060 & 0.803 & 31 \\
\hline & Subalpine coniferous & 1.050 & 1.045 & 0.755 & 25 \\
\hline & Deciduous & 1.110 & 1.048 & 0.864 & 49 \\
\hline & Evergreen & 1.275 & 0.839 & 0.697 & 22 \\
\hline \multirow[t]{7}{*}{ Phosphorus } & Cedar & -0.371 & 1.054 & 0.443 & 43 \\
\hline & Cypress & -0.359 & 1.003 & 0.598 & 26 \\
\hline & Pine & -0.047 & 0.920 & 0.903 & 10 \\
\hline & Todo fir & -0.397 & 1.337 & 0.709 & 30 \\
\hline & Subalpine coniferous & 0.089 & 0.923 & 0.535 & 18 \\
\hline & Deciduous & 0.233 & 0.678 & 0.547 & 30 \\
\hline & Evergreen & -0.454 & 1.202 & 0.725 & 14 \\
\hline \multirow[t]{8}{*}{ Potassium } & Cedar & -0.093 & 1.107 & 0.547 & 96 \\
\hline & Cypress & 0.124 & 1.004 & 0.609 & 46 \\
\hline & Larch & -0.087 & 1.198 & 0.682 & 16 \\
\hline & Pine & 0.343 & 0.810 & 0.753 & 15 \\
\hline & Todo fir & 0.277 & 0.965 & 0.700 & 29 \\
\hline & Subalpine coniferous & 0.633 & 0.680 & 0.672 & 13 \\
\hline & Deciduous & -0.372 & 1.200 & 0.348 & 33 \\
\hline & Evergreen & 0.223 & 0.890 & 0.581 & 16 \\
\hline \multirow[t]{8}{*}{ Calcium } & Cedar & 1.292 & 0.840 & 0.646 & 96 \\
\hline & Cypress & 0.949 & 0.836 & 0.676 & 44 \\
\hline & Larch & 0.878 & 0.958 & 0.613 & 16 \\
\hline & Pine & 1.134 & 0.645 & 0.631 & 15 \\
\hline & Todo fir & 0.063 & 1.603 & 0.574 & 27 \\
\hline & Subalpine coniferous & 1.328 & 0.668 & 0.393 & 12 \\
\hline & Deciduous & 1.248 & 0.522 & 0.128 & 33 \\
\hline & Evergreen & 1.705 & 0.397 & 0.102 & 16 \\
\hline \multirow[t]{6}{*}{ Magnesium } & Cedar & -0.003 & 1.148 & 0.612 & 92 \\
\hline & Cypress & 0.166 & 0.382 & 0.567 & 41 \\
\hline & Larch & 0.353 & 0.853 & 0.576 & 15 \\
\hline & Pine & 0.634 & 0.567 & 0.538 & 15 \\
\hline & Deciduous & -0.117 & 1.083 & 0.381 & 32 \\
\hline & Evergreen & 0.694 & 0.595 & 0.209 & 16 \\
\hline
\end{tabular}




\section{References}

1. IPCC. 2006 IPCC Guidelines for National Greenhouse Gas Inventories; Prepared by National Greenhouse Gas Inventories Programme; Eggleston, H.S., Buendia, L., Miwa, K., Ngara, T., Tanabe, K., Eds.; IGES: Kanagawa, Japan, 2006; ISBN 978-4-88788-032-0.

2. Takahashi, M. Comparison of nutrient concentrations in organic layers between broad-leaved and coniferous forests. Soil Sci. Plant Nutr. 1997, 43, 541-550. [CrossRef]

3. Lee, S.J.; Yim, J.S.; Son, Y.M.; Son, Y.; Kim, R. Estimation of Forest Carbon Stocks for National Greenhouse Gas Inventory Reporting in South Korea. Forests 2018, 9, 625. [CrossRef]

4. Domke, G.M.; Perry, C.; Walters, B.; Woodall, C.W.; Russell, M.B.; Smith, J.E. Estimating litter carbon stocks on forest land in the United States. Sci. Total Environ. 2016, 557-558, 469-478. [CrossRef] [PubMed]

5. Joo, S.J.; Yim, M.H.; Nakane, K. Contribution of microarthropods to the decomposition of needle litter in a Japanese cedar (Cryptomeria japonica D. Don) plantation. For. Ecol. Manag. 2006, 234, 192-198. [CrossRef]

6. Petersen, H.; Luxton, M. A Comparative Analysis of Soil Fauna Populations and Their Role in Decomposition Processes. Oikos 1982, 39, 288. [CrossRef]

7. Saitoh, S.; Fujii, S.; Takeda, H. Evaluation of the bottom-up force of accumulated organic matter on microarthropods in a temperate forest floor. Eur. J. Soil Biol. 2011, 47, 409-413. [CrossRef]

8. Li, X.; Yin, X.; Wang, Z.; Fan, W. Interaction between decomposing litter and soil fauna of the Betula ermanii forest floor of the Changbai Mountains, China. Can. J. For. Res. 2014, 44, 1507-1514. [CrossRef]

9. Gosz, J.R.; Likens, G.E.; Bormann, F.H. Organic matter and nutrient dynamics of the forest and forest floor in the Hubbard Brook Forest. Oecologia 1976, 22, 305-320. [CrossRef] [PubMed]

10. Hayashi, S.; Sudo, R. Role of litter in acid buffer capacity in forest area. Environ. Sci. 1997, 10, 11-19. [CrossRef]

11. Jiang, J.; Wang, Y.; Yu, M.; Cao, N.; Yan, J. Soil organic matter is important for acid buffering and reducing aluminum leaching from acidic forest soils. Chem. Geol. 2018, 501, 86-94. [CrossRef]

12. Berg, B.; McClaugherty, C. Plant Litter: Decomposition, Humus Formation, Carbon Sequestration, 4th ed.; Springer: Berlin/Heidelberg, Germany, 2020; ISBN 978-3-030-59630-9.

13. Osono, T.; Takeda, H. Decomposition of organic chemical components in relation to nitrogen dynamics in leaf litter of 14 tree species in a cool temperate forest. Ecol. Res. 2004, 20, 41-49. [CrossRef]

14. Aber, J.D.; Melillo, J.M.; McClaugherty, C.A. Predicting long-term patterns of mass loss, nitrogen dynamics, and soil organic matter formation from initial fine litter chemistry in temperate forest ecosystems. Can. J. Bot. 1990, 68, 2201-2208. [CrossRef]

15. Yue, K.; Ni, X.; Fornara, D.A.; Peng, Y.; Liao, S.; Tan, S.; Wang, D.; Wu, F.; Yang, Y. Dynamics of Calcium, Magnesium, and Manganese During Litter Decomposition in Alpine Forest Aquatic and Terrestrial Ecosystems. Ecosystems 2020, $24,516-529$. [CrossRef]

16. Kaneko, N.; Katagiri, N.; Miyake, N. Decomposition process of needle litter of Japanese Red Cedar (Cryptomeria japonica) by oribatid mites. J. Jpn. For. Soc. 1990, 72, 158-162. [CrossRef]

17. Ge, X.; Zeng, L.; Xiao, W.; Huang, Z.; Geng, X.; Tan, B. Effect of litter substrate quality and soil nutrients on forest litter decomposition: A review. Acta Ecol. Sin. 2013, 33, 102-108. [CrossRef]

18. Takahashi, M.; Matoba, S.; Sato, T. Size distribution and concentration of carbon and nitrogen in each size class of organic matter in the organic layers under a Pinus pumila stand. Jpn. J. For. Environ. 1996, 38, 109-114. [CrossRef]

19. Kanazawa, S.; Wada, H.; Takesima, S.; Takai, Y. The decomposition processes and existence forms of organic matter in subalpine forest soil (Part 1): Microscopic observation and carbon-nitrogen content of fractionated organic layer of Pwh soil type of Mt. Shigayama. Jpn. J. Soil Sci. Plant Nutr. 1977, 48, 181-186. [CrossRef]

20. Vogt, K.A.; Grier, C.C.; Meier, C.E.; Keyes, M.R. Organic Matter and Nutrient Dynamics in Forest Floors of Young and Mature Abies amabilis Stands in Western Washington, as Affected by Fine-Root Input. Ecol. Monogr. 1983, 53, 139-157. [CrossRef]

21. Carnol, M.; Bazgir, M. Nutrient return to the forest floor through litter and throughfall under 7 forest species after conversion from Norway spruce. For. Ecol. Manag. 2013, 309, 66-75. [CrossRef]

22. Tobón, C.; Sevink, J.; Verstraten, J.M. Litterflow chemistry and nutrient uptake from the forest floor in northwest Amazonian Forest ecosystems. Biogeochemistry 2004, 69, 315-339. [CrossRef]

23. Zechmeister-Boltenstern, S.; Keiblinger, K.M.; Mooshammer, M.; Penuelas, J.; Richter, A.; Sardans, J.; Wanek, W. The application of ecological stoichiometry to plant-microbial-soil organic matter transformations. Ecol. Monogr. 2015, 85, 133-155. [CrossRef]

24. Moore, T.R.; Trofymow, J.A.; Prescott, C.E.; Fyles, J.; Titus, B.D. Patterns of Carbon, Nitrogen and Phosphorus Dynamics in Decomposing Foliar Litter in Canadian Forests. Ecosystems 2006, 9, 46-62. [CrossRef]

25. Wen-Ji, M.; Yan-Tao, Z.; Qing-Qing, Z.; Arshad, A.; Qing-Ru, S.; En-Rong, A.Y. C:N:P stoichiometry in forest floor litter of evergreen broad-leaved forests at different successional stages in Tiantong, Zhejiang, eastern China. Chin. J. Plant Ecol. 2014, 38, 833-842. [CrossRef]

26. Tsukada, M. Vegetation and Climate during the Last Glacial Maximum in Japan. Quat. Res. 1983, 19, 212-235. [CrossRef]

27. Nakashizuka, T.; Iida, S. Composition, dynamics and disturbance regime of temperate deciduous forests in Monsoon Asia. Vegetatio 1995, 121, 23-30. [CrossRef]

28. Covington, W.W. Changes in Forest Floor Organic Matter and Nutrient Content Following Clear Cutting in Northern Hardwoods. Ecology 1981, 62, 41-48. [CrossRef] 
29. Zajícová, K.; Chuman, T. Spatial variability of forest floor and topsoil thicknesses and their relation to topography and forest stand characteristics in managed forests of Norway spruce and European beech. Eur. J. For. Res. 2020, 140, 77-90. [CrossRef]

30. Tokuchi, N.; Takeda, H.; Yoshida, K.; Iwatsubo, G. Topographical variations in a plant-soil system along a slope on Mt Ryuoh, Japan. Ecol. Res. 1999, 14, 361-369. [CrossRef]

31. Takahashi, M. Direct estimation of carbon mass of organic layer from dry weight. J. For. Res. 2005, 10, 239-241. [CrossRef]

32. Morita, K. Mineral composition of the fresh litter of major tree species in Japan. Bull. Gov. For. Exp. Sta. 1972, $243,33-50$.

33. Takahashi, M.; Ishizuka, S.; Ugawa, S.; Sakai, Y.; Sakai, H.; Ono, K.; Hashimoto, S.; Matsuura, Y.; Morisada, K. Carbon stock in litter, deadwood and soil in Japan's forest sector and its comparison with carbon stock in agricultural soils. Soil Sci. Plant Nutr. 2010, 56, 19-30. [CrossRef]

34. Mashimo, Y. Evaluation of forest growth by quantification of environmental factors. JARQ Jpn. Agric. Res. Q. 1978, $12,232-237$.

35. Katagiri, N.; Miyake, N.; Fujiwara, Y. Distribution and stand structure of natural Japanese Red-Pine (Pinus Densiflora S. et Z.) in Sanbe Forest of Shimane University. Bull. Fac. Agric. 1987, 21, 39-45.

36. Umezu, K. History and transition of the coastal forest in Japan-Focusing on the Shonai coastal forest. Tree For. Health 2016, 20, 104-111. [CrossRef]

37. Franklin, J.F.; Maeda, T.; Ohsumi, Y.; Matsui, M.; Yagi, H.; Hawk, G.M. Subalpine Coniferous Forests of Central Honshu, Japan. Ecol. Monogr. 1979, 49, 311-334. [CrossRef]

38. Takehara, H.; Kubo, T.; Hosokawa, K. Forest soils derived from granite and palaeozoic sedimentary rocks in Kiso region. J. Jpn. For. Soc. 1959, 41, 436-444. [CrossRef]

39. Takata, K.; Kurinobu, S.; Koizumi, A.; Yasue, K.; Tamai, Y.; Kisanuki, M. Bibliography on Japanese larch (Larix kaempferi (Lamb.) Carr.). Eurasian J. For. Res. 2005, 8, 111-126.

40. Haruki, M. Studies on the material biomass of Abies sachalinensis artificial forest. Res. Bull. Hokkai-Do Univ. For. 1979, 36, 147-254.

41. Yamada, H.; Miyaura, T. Geographic variation in nut size of Castanopsis species in Japan. Ecol. Res. 2004, 20, 3-9. [CrossRef]

42. Sakai, M.; Inoue, K. Amount of migrated coarse organic matter into soil (V)—Monthly changes in Japanese cedar fallen litter on the forest floor by photograph. In Annual Report of the Shikoku Branch; Forestry and Forest Products Research Institute: Ibaraki, Japan, 1987; Volume 28, pp. 24-27.

43. Miura, S.; Ugawa, S.; Yoshinaga, S.; Hirai, T.Y.K. Floor Cover Percentage Determines Splash Erosion in Chamaecyparis obtuse Forests. Soil Sci. Soc. Am. J. 2015, 79, 1782-1791. [CrossRef]

44. Ichikawa, T.; Takahashi, T.; Asano, Y. Comparison of Changes in Organic Matter Dynamics due to Stand Age between Artificial Japanese Cedar (Cryptomeria japonica D. Don) Forests and Japanese Cypress (Chamaecyparis obtusa Sieb. et Zucc.) Forests. J. Jpn. For. Soc. 2006, 88, 525-533. [CrossRef]

45. Kiyono, Y. Analyses of factors affecting Ao-Layer overage in Chamaecypayis obtusa plantations. J. Jpn. For. Soc. 1988, 70, 71-74. [CrossRef]

46. Miura, S.; Yoshinaga, S.; Yamada, T. Protective effect of floor cover against soil erosion on steep slopes forested with Chamaecyparis obtusa (hinoki) and other species. J. For. Res. 2003, 8, 27-35. [CrossRef]

47. Hattori, S.; Abe, T.; Kobayashi, C.; Tamai, K. Effect of forest floor coverage on reduction of soil erosion in Hinoki plantations. Bull. For. For. Prod. Res. Inst. 1992, 362, 1-34.

48. Ichikawa, T.; Takahashi, T.; Kobayashi, T. The relation between the population of the earthworm and types of vegetation or soil environment. J. Jpn. Soc. Reveg. Technol. 2008, 34, 15-20. [CrossRef]

49. Ohta, T.; Niwa, S.; Agetsuma, N.; Hiura, T. Calcium concentration in leaf litter alters the community composition of soil invertebrates in warm-temperate forests. Pedobiologia 2014, 57, 257-262. [CrossRef]

50. Takeda, H. A 5-year study of litter decomposition processes in a Chamaecyparis obtusa Endl. forest. Ecol. Res. 1995, 10, 95-104. [CrossRef]

51. Akai, T.; Asada, S. Studies on natural reproduction (I) The reproduction of Chamaecyparis at Wet Podzolic zone in Kiso district. Bull. Kyoto Univ. For. 1967, 39, 35-63.

52. Watanabe, M.; Yamaguchi, M.; Tabe, C.; Iwasaki, M.; Yamashita, R.; Funada, R.; Fukami, M.; Matsumura, H.; Kohno, Y.; Izuta, $\mathrm{T}$. Influences of nitrogen load on the growth and photosynthetic responses of Quercus serrata seedlings to O3. Trees 2007, 21, 421-432. [CrossRef]

53. Yamanaka, T.; Hirai, K.; Aizawa, S.; Yoshinaga, S.; Takahashi, M. Nitrogen-fixing activity in decomposing litter of three tree species at a watershed in eastern Japan. J. For. Res. 2011, 16, 1-7. [CrossRef]

54. Sawata, S.; Kato, H. Effect of Forest on Soil (Part 2): The base accumulation and other soil properties related to age of Cryptomeria and Japanese cypress stands. Jpn. J. Soil Sci. Plant Nutr. 1991, 62, 49-58. [CrossRef]

55. Baba, M.; Kato, M.; Sugiura, T.; Kobayashi, H. Calcium accumulation alleviates soil acidification in Japanese cedar (Cryptomeria japonica) stands. Soil Sci. Plant Nutr. 2004, 50, 403-411. [CrossRef]

56. Tanikawa, T.; Ito, Y.; Fukushima, S.; Yamashita, M.; Sugiyama, A.; Mizoguchi, T.; Okamoto, T.; Hirano, Y. Calcium is cycled tightly in Cryptomeria japonica stands on soils with low acid buffering capacity. For. Ecol. Manag. 2017, 399, 64-73. [CrossRef]

57. Harada, H.; Satoo, H.; Hotta, I.; Hatiya, K.; Tadaki, Y. Study on the nutrient contents of mature Cryptomeria forest. Bull. Gov. For. Exp. Stn. 1972, 249, 17-74.

58. Takahashi, M. Water soluble elements in decomposing Japanese cedar needle litter. Soil Sci. Plant Nutr. 1996, 42, 395-399. [CrossRef] 
59. Velázquez, E.; Silva, L.R.; Ramírez-Bahena, M.H.; Peix, A. Diversity of potassium-solubilizing microorganisms and their interactions with plants. In Potassium Solubilizing Microorganisms for Sustainable Agriculture; Springer: New Delhi, India, 2016; pp. 99-110. ISBN 9788132227762.

60. Osono, T.; Takeda, H. Potassium, calcium, and magnesium dynamics during litter decomposition in a cool temperate forest. J. For. Res. 2004, 9, 23-31. [CrossRef]

61. Osono, T. Hyphal length in the forest floor and soil of subtropical, temperate, and subalpine forests. J. For. Res. 2015, 20, 69-76. [CrossRef]

62. Vinichuk, M.; Taylor, A.; Rosén, K.; Johanson, K. Accumulation of potassium, rubidium and caesium (133Cs and 137Cs) in various fractions of soil and fungi in a Swedish forest. Sci. Total Environ. 2010, 408, 2543-2548. [CrossRef] [PubMed]

63. Yoshida, S.; Muramatsu, Y. Concentrations of radiocesium and potassium in Japanese mushrooms. Environ. Sci. 1994, 7, 63-70. [CrossRef]

64. Cromack, K.; Todd, R.L.; Monk, C.D. Patterns of basidiomycete nutrient accumulation in conifer and deciduous forest litter. Soil Biol. Biochem. 1975, 7, 265-268. [CrossRef]

65. Saito, H. Materials for the studies of litterfall in forest stands. Bull. Kyoto Prefect. Univ. For. 1981, 25, 78-89.

66. Lang, F.; Krüger, J.; Amelung, W.; Willbold, S.; Frossard, E.; Bünemann, E.K.; Bauhus, J.; Nitschke, R.; Kandeler, E.; Marhan, S.; et al. Soil phosphorus supply controls P nutrition strategies of beech forest ecosystems in Central Europe. Biogeochemistry 2017, 136, 5-29. [CrossRef]

67. Reich, P.B.; Oleksyn, J. Global patterns of plant leaf N and P in relation to temperature and latitude. Proc. Natl. Acad. Sci. USA 2004, 101, 11001-11006. [CrossRef]

68. Li, P.; Yang, Y.; Han, W.; Fang, J. Global patterns of soil microbial nitrogen and phosphorus stoichiometry in forest ecosystems. Glob. Ecol. Biogeogr. 2014, 23, 979-987. [CrossRef]

69. Kunito, T.; Tsunekawa, M.; Yoshida, S.; Park, H.-D.; Toda, H.; Nagaoka, K.; Saeki, K. Soil Properties Affecting Phosphorus Forms and Phosphatase Activities in Japanese Forest Soils. Soil Sci. 2012, 177, 39-46. [CrossRef]

70. Nanzyo, M.; Dahlgren, R.; Shoji, S. Chapter 6 Chemical Characteristics of Volcanic Ash Soils. Dev. Soil Sci. 1993, 145-187. [CrossRef]

71. Stahr, S.; Graf-Rosenfellner, M.; Klysubun, W.; Mikutta, R.; Prietzel, J.; Lang, F. Phosphorus speciation and C:N:P stoichiometry of functional organic matter fractions in temperate forest soils. Plant Soil 2017, 427, 53-69. [CrossRef]

72. Walker, T.; Syers, J. The fate of phosphorus during pedogenesis. Geoderma 1976, 15, 1-19. [CrossRef]

73. Johnson, D.W.; Richter, D.D.; Van Miegroet, H.; Cole, D.W. Contributions of Acid Deposition and Natural Processes to Cation Leaching from Forest Soils: A Review. J. Air Pollut. Control. Assoc. 1983, 33, 1036-1041. [CrossRef]

74. Dijkstra, F.A.; Geibe, C.; Holmström, S.; Lundström, U.S.; Van Breemen, N. The effect of organic acids on base cation leaching from the forest floor under six North American tree species. Eur. J. Soil Sci. 2001, 52, 205-214. [CrossRef]

75. Vesterdal, L.; Raulund-Rasmussen, K. Forest floor chemistry under seven tree species along a soil fertility gradient. Can. J. For. Res. 1998, 28, 1636-1647. [CrossRef]

76. Hamburg, S.P.; Yanai, R.D.; Arthur, M.A.; Blum, J.D.; Siccama, T.G. Biotic Control of Calcium Cycling in Northern Hardwood Forests: Acid Rain and Aging Forests. Ecosystems 2003, 6, 399-406. [CrossRef]

77. MacLean, D.A.; Wein, R.W. Litter production and forest floor nutrient dynamics in pine and hardwood stands of New Brunswick, Canada. Ecography 1978, 1, 1-15. [CrossRef]

78. Currie, W.S.; Aber, J.D.; Driscoll, C.T. Leaching of nutrient cations from the forest floor: Effects of nitrogen saturation in two long-term manipulations. Can. J. For. Res. 1999, 29, 609-620. [CrossRef]

79. Wessel, W.W.; Tietema, A. Metal distribution across different pools in the organic layer of a forest under acid deposition and its consequences for the metal dynamics. Plant Soil 1995, 171, 341-350. [CrossRef] 